\title{
LONG-TERM OUTCOME OF HEPATITIS B AND HEPATITIS C VIRUS CO-INFECTION AND SINGLE HBV INFECTION ACQUIRED IN YOUTH.
}

\begin{tabular}{|c|c|}
\hline Journal: & Journal of Medical Virology \\
\hline Manuscript ID: & JMV-09-1210.R1 \\
\hline Wiley - Manuscript type: & Research Article \\
\hline $\begin{array}{r}\text { Date Submitted by the } \\
\text { Author: }\end{array}$ & 30-Apr-2009 \\
\hline Complete List of Authors: & $\begin{array}{l}\text { Zampino, Rosa; Second University of Naples, Internal medicine and } \\
\text { Hepatology } \\
\text { Marrone, Aldo } \\
\text { Merola, Antonietta } \\
\text { Trani, Barbara } \\
\text { Cirillo, Grazia; SUN, Paediatrics } \\
\text { Karayiannis, Peter; Imperial College, Medicine } \\
\text { Coppola, Nicola; SUN, Public Medicine Infectious Diseases Section } \\
\text { Zappalà, Rosario } \\
\text { Utili, Riccardo } \\
\text { Ruggiero, Giuseppe; Second University of Naples, Internal medicine } \\
\text { and Hepatology } \\
\text { Adinolfi, Luigi; Second University of Naples, Internal medicine and } \\
\text { Hepatology }\end{array}$ \\
\hline Keywords: & HBV-HCV co-infection, chronic hepatitis, long-term outcome \\
\hline
\end{tabular}

\section{S ScholaroNE" \\ Manuscript Central}


Fig.1

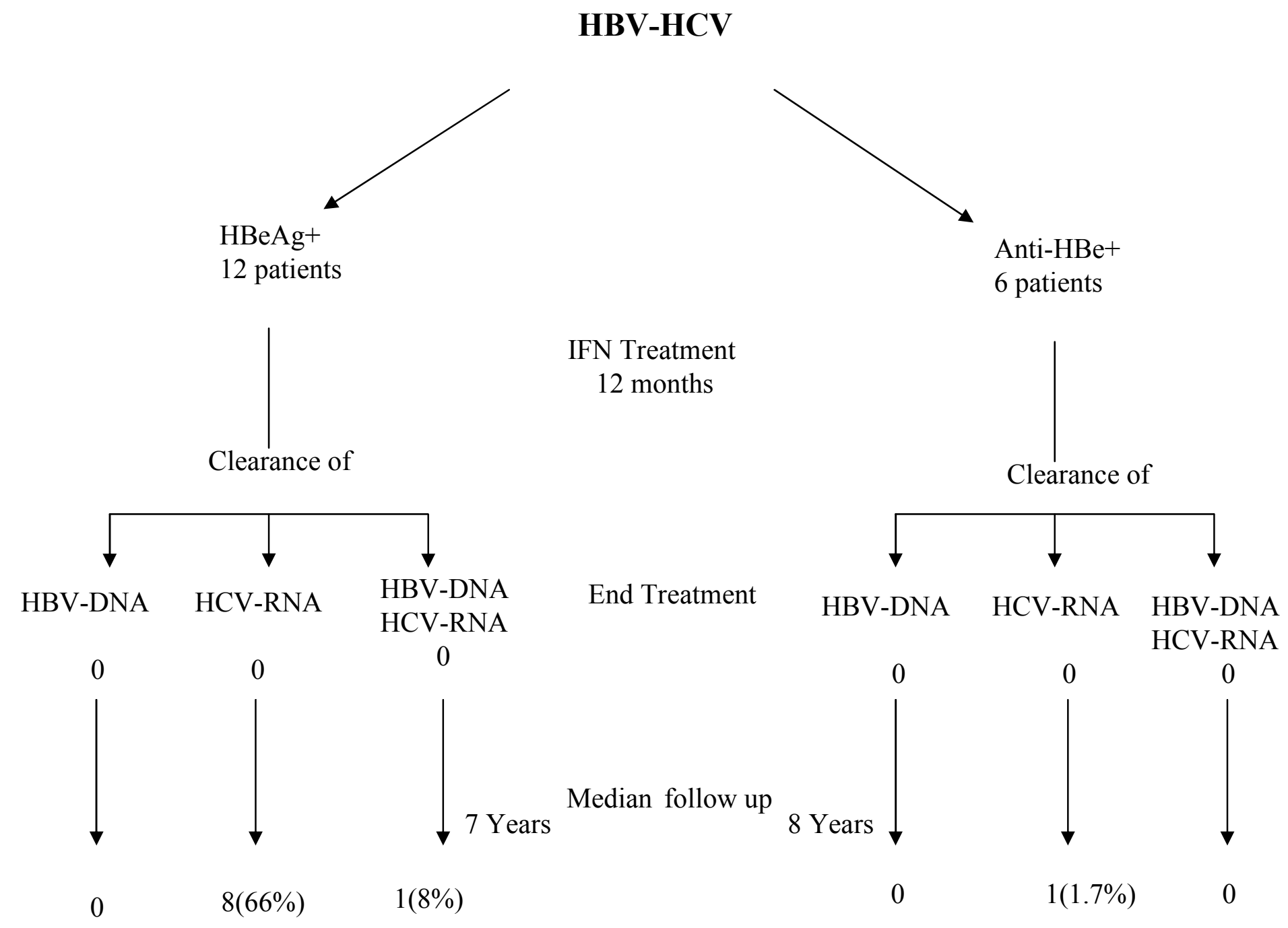


Fig 2

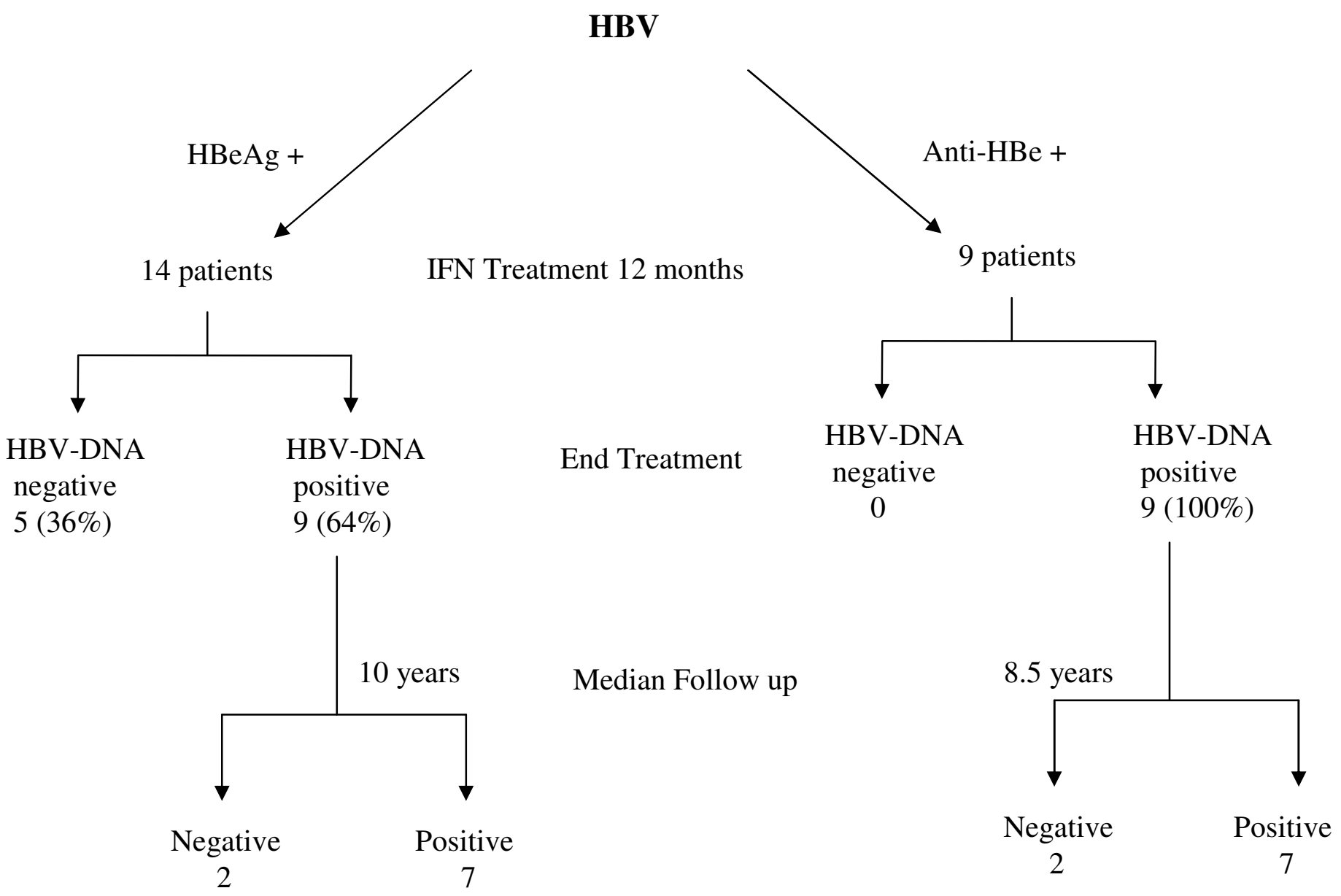


Fig.3

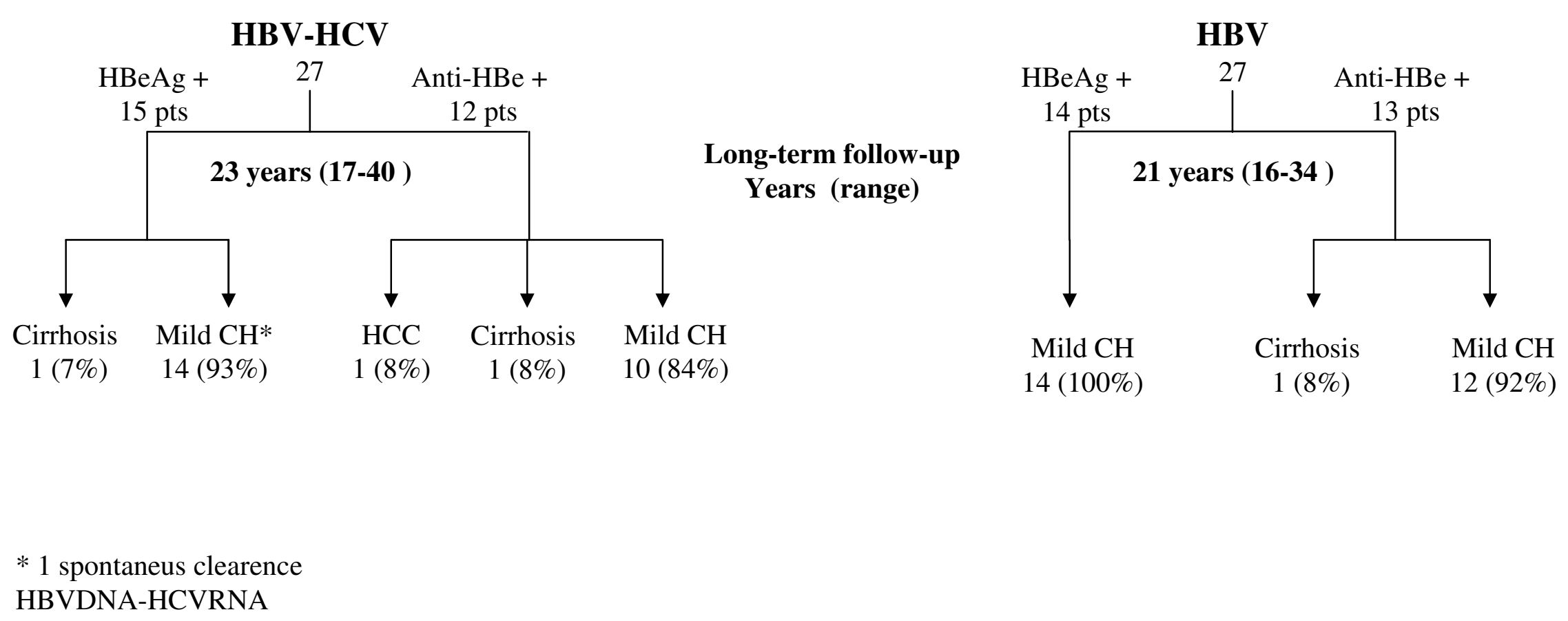




\section{LONG-TERM OUTCOME OF HEPATITIS B AND HEPATITIS C VIRUS CO- INFECTION AND SINGLE HBV INFECTION ACQUIRED IN YOUTH.}

Rosa Zampino ${ }^{1}$, Aldo Marrone ${ }^{1}$, Antonietta Merola ${ }^{1}$, Barbara Trani ${ }^{1}$, Grazia Cirillo ${ }^{2}$, Peter Karayiannis $^{6}$, Nicola Coppola ${ }^{3}$, Rosario Zappalà ${ }^{5}$, Riccardo Utili ${ }^{4}$, Giuseppe Ruggiero ${ }^{1}$ and Luigi E. Adinolfi ${ }^{1}$.

${ }^{1}$ Internal Medicine and Hepatology, ${ }^{2}$ Department of Pediatrics, ${ }^{3}$ Department of Public Medicine Infectious Diseases Section, ${ }^{4}$ Unit of Infectious Disease and Transplant Medicine, Second University of Naples, ${ }^{5}$ Evangelic Betania Foundation, Naples, Italy, ${ }^{6}$ Imperial College, St. Mary’s Hospital, London, U.K.

Short title: HBV-HCV co-infection long-term follow up

\section{Corresponding author:}

Dr. Rosa Zampino, M.D.

Internal Medicine and Hepatology

Second University of Naples

Via Cotugno, 1 (c/o Osp. Gesù e Maria)

80135 Naples

Italy

Phone: 00390815666270

Fax: 00390815666230

e-mail: rosa.zampino@unina2.it 


\begin{abstract}
Co-infection with HBV and HCV seems to be associated with more severe liver disease in retrospective and cross-sectional studies in adults, but no data are available when co-infection is acquired in youth. The long-term outcome of infection acquired in youth was assessed in patients co-infected with HBV and HCV and in patients with HBV infection only.

Twenty-seven patients with HBV and HCV co-infection and 27 patients infected with HBV only were enrolled. Seventy-six per cent of the patients were treated with $\alpha$-interferon for one year. After a median follow up of 23 years, the annual progression rate of fibrosis was 0.07 in patients coinfected with HBV and HCV, and in those infected with HBV it was 0.07 and $0.11(\mathrm{p}<0.004)$ for $\mathrm{HBe}$ and anti-HBe positive patients, respectively. In co-infected patients the development of cirrhosis was observed in $2(7.4 \%)$ and of hepatocellular carcinoma (HCC) in $1(3.7 \%)$, while in those with $\mathrm{HBV}$, cirrhosis appeared in one patient $(3.7 \%)$. Alcohol intake $(\mathrm{OR}=9.5 \pm 1.2 ; 95 \% \mathrm{CI}$ $=6.6-13.9 ; \mathrm{p}<0.0001)$ was independently associated with cirrhosis and HCC. $\alpha$-interferon showed no efficacy during treatment, but the treated group showed higher HCV RNA clearance during posttreatment follow up.

Co-infection with HBV and HCV and single HBV infection acquired in youth showed a low rate of progression to liver fibrosis, no liver failure and low development of HCC during a median follow up of 23 years (range 17-40).
\end{abstract}

Abstract word count: 236

Key words: HBV-HCV co-infection, chronic hepatitis, long-term outcome 
Worldwide, hepatitis B (HBV) and hepatitis C (HCV) viruses are responsible for most of the cases of liver disease and hepatocellular carcinoma (HCC) [Lavanchy, 2004; Lauer \& Walker, 2001]. Several factors have been suggested to influence the rate of progression of chronic hepatitis, such as co-infection with $\mathrm{HBV}, \mathrm{HCV}$ or HIV, age at infection, gender, alcohol intake and viral genomic mutations. Retrospective cohort and cross-sectional studies have shown that co-infection with HBV and HCV is associated with a more severe liver disease, an increased risk of HCC [Sagnelli et al, 2000; Mathrurin et al, 2000; Marcellin et al, 2002] and viral interference, with a dynamic dominance of one virus over the other [Pontisso et al, 1993; Utili et al, 1999; Liaw, 1995; Raimondo et al, 2006].

In endemic areas, anti-HCV antibodies are detectable in about $7 \%$ of patients with chronic HBV infection; co-infection increases with age and is more common in patients older than 50 years [Gaeta et al, 2003].

The natural history of chronic HBV infection is characterised by the emergence of genomic mutations in the core-promoter and/or the pre-core regions. Such genomic mutations have been associated with the presence or absence of $\mathrm{HBeAg}$, with a higher rate of progression of liver fibrosis, transaminase flares and fulminant liver failure [Friedt et al, 1999; Lindh et al, 1999, Zampino et al, 2002]. In contrast, patients co-infected with HBV and HCV seem to have a lower rate of genomic mutations of $\mathrm{HBV}$, and the appearance of these mutations does not seem to be involved in the reciprocal inhibition of viral replication [Yeh et al 1994; Jardi et al, 2001].

The host immune response is another factor that may modulate viral replication and the progression of liver damage. It has been reported that HBV infection regulates TNF- $\alpha$ expression and production, both in vivo and in vitro, suggesting that cytokines may have a role in the development of liver disease [Gonzales-Amaro et al, 1994]. In a transgenic mouse model it was shown that the induction of TNF- $\alpha$ regulates negatively the gene expression of HBV [Gilles et al, 1992]. In chronic HCV infection, a Th2 cytokine profile seems to be associated with a more severe outcome of the liver disease [Gramenzi et al, 2005]. 
1

2

3

4

5

6

7

8

At present, in the absence of prospective studies with a known date of infection and of other contributing factors over time, the real natural history remains obscure. In addition, no data are available on the natural history of co-infection with HBV and HCV acquired at a young age.

Accordingly, the aim of this study was to assess the long-term clinical outcome in a cohort of patients with co-infection with HBV and HCV or HBV infection only, acquired in childhood or in adolescence, and to evaluate the factors associated with the possible progression of the hepatic disease, in particular, the impact of virological and host immunological parameters on the course of the disease. 


\section{Materials and Methods}

\section{Patients}

A cohort of 54 consecutive Italian patients with active co-infection with HBV and HCV or active HBV infection acquired in youth and followed up prospectively at the Liver Unit of the Second University of Naples were evaluated for long-term liver disease outcome.

Until 1990, before a serological test for HCV became available, the patients were referred as infected with HBV. All patients had a known date of HBV infection and had been on regular follow up since their infection or shortly thereafter. Sera were collected at least once a year and stored at $-80^{\circ} \mathrm{C}$. Stored sera were tested for the presence of HBV DNA and HCV RNA when these molecular tests became available. On the first serum samples, collected between 8 and 38 months (median 16 months) after infection with HBV, 27 patients had HBV DNA and HCV RNA and 27 patients were HBV DNA positive only. No patient was positive by serology for HDV and/or HIV at the first observation, nor became positive at any time. Patients were evaluated at least once a year with physical examination, measurement of liver function tests, $\alpha$-fetoprotein, blood cell count, hepatic viral markers, liver ultrasound scan and other risk factors for liver disease, such as alcohol and drug use. All patients underwent at least one liver biopsy. The histological activity index (HAI) was scored according to Knodell et al. [1981] and staging according to Scheuer [1991].

At the end of the follow-up period a second liver biopsy was performed in 20 patients and fibrosis was scored according to Scheuer [1991] and to METAVIR [Bedossa et al, 1996]. The METAVIR fibrosis score was compared with that obtained by transient elastography (FibroScan®), Echosense, Paris, France), a validated non-invasive method to quantify hepatic fibrosis [Sandrin et al, 2003; Castera et al, 2008]. The operator was an expert staff physician who had performed previously about 300 examinations in patients with chronic liver disease. Since a good correlation between the two methods was found, a liver biopsy was not performed for the other patients and the fibrosis score was assessed only by transient elastography. 
During the follow up, 41 of the 54 patients were treated with $\alpha$-interferon $(\alpha-I F N), 5 \mathrm{MU} / \mathrm{m}^{2}$ t.i.w. for 12 months. The end points of treatment were HBV-DNA and/or HCV-RNA clearance. In HBeAg positive patients, $\mathrm{HBeAg} / \mathrm{anti}-\mathrm{HBe}$ seroconversion was also evaluated. Thirteen patients were not treated because of contraindications or because they refused treatment.

HBV genomic analysis, including core promoter, pre-core and core regions, and serum detection of Th1-Th2 cytokines were evaluated on serum samples taken simultaneously at the first liver biopsy.

The principles outlined in the Declaration of Helsinki were adhered to in carrying out this study and each patient's full consent was obtained.

\section{Serological determinations}

Serum markers for HBV, HCV, HDV and HIV infection were tested using commercially available immunoenzymatic assays (Abbott Laboratories, North Chicago, IL. U.S.A. and Ortho Diagnostic Systems, Raritan, NJ, U.S.A.).

\section{Quantitative HBV DNA and HCV RNA}

DNA was extracted with the QIAamp DNA Mini Kit (Qiagen, Hilden, Germany) and RNA by QIAamp Viral RNA equivalent (Qiagen, Hilden, Germany).

HBV DNA real-time PCR was performed in a Light-cycler 1.5 (Roche Diagnostics, Branchburg, NJ, USA). Forward and reverse primers, located in the core region of HBV, were $5^{1}$ TTTTTCACCTCTGCCTAATCATC- $3^{1}$ nt 8-30, and $5^{1}$-ACCCACCCAGGTAGCTAGAGTCAT$3^{1}$ nt 306-289. Using a commercially available standard of HBV viral load (Accuran HBV DNA, BBI Diagnostics, West Bridgewater, MA, USA) the detection limit was 100 copies/mL.

HCV RNA real-time PCR was performed using the same Light-cycler 1.5. Forward and reverse primers, located in the 5-UTR region, were $5^{1}$-AGCGTCTAGCCATGGCGT- $3^{1}$ nt 74-91, and $5^{1}$-CAAGCACCCTATCAGGCAGT- $3^{1}$ nt 308-288. FRET hybridization probes were $5^{1}$ - 
GCAGCCTCCAGGACCCCCC-FL- $3^{1}$ and $5^{1}-\mathrm{R}_{640}$-CCCGGGAGAGCCATAGTGGTCTC-p-3 $3^{1}$. Using a commercial standard of HCV viral load (Accuran HCV RNA, BBI Diagnostics, West Bridgewater, MA, USA) the detection limit was 200 copies $/ \mathrm{mL}$.

\section{HBV genomic analysis, HBV and HCV genotype}

For the HBV molecular study, the extraction, amplification, sequencing and computer analysis of the sequences were performed as described previously [Zampino et al, 2002].

HBV and HCV genotypes were determined using Inno-Lipa HBVDR (Innogenetics N.V.; Ghent, Belgium) and HCV genotype assay Lipa (Bayer, France), respectively, following the manufacturer's instructions.

\section{Serum cytokines}

IL-2, IL-4, IL-8, IL-10, IL-12, IL-13, $\gamma$-IFN and TNF- $\alpha$ were detected by multiple sandwich ELISA using Human Search Light TM Proteome Array for human Th1/Th2 cytokines (Pierce Biotechnology, Rockford, IL, USA), according to the manufacturer's instructions.

\section{Statistical analysis}

The comparisons between the groups were made by the Mann-Whitney U test and by Fisher's exact test. Multiple logistic regression analysis was used to evaluate the factors independently associated with the development of liver cirrhosis and HCC. The odds ratio (OR) with 95\% confidence interval (CI) was determined. A p-value $<0.05$ was considered statistically significant. Statistical analysis was performed using the SPSS (SPSS Inc.,Chicago, IL, USA) software for Windows (Version 12.0). 


\section{Results}

\section{Characteristics of patients}

Table I shows the characteristics of the study population at first liver biopsy. The infection was acquired in $44 \%$ of patients by transfusion, in $32 \%$ by surgery, in $3 \%$ by intravenous drug use and in $21 \%$ by intra-family contact.

\section{Serum HBV DNA and HCV RNA levels}

Serum HBV DNA and HCV RNA levels were determined at least once a year. In the group with HBV and HCV co-infection, low and comparable HCV RNA serum levels were observed in $\mathrm{HBeAg}$ and anti-HBe positive patients (Table I). In the patients with HBV and HCV co-infection and patients with HBV infection only, the HBV DNA serum levels were higher in HBeAg positive than in anti-HBe positive patients (Table I). However, an analysis of the subgroups showed that the anti-HBe positive patients with $\mathrm{HBV}$ and $\mathrm{HCV}$ co-infection had significantly lower HBV DNA levels than those observed in the anti-HBe positive patients with HBV (Table I, p=0.001).

\section{HBV genomic analysis: core promoter, pre-core and core regions}

Table II shows the HBV mutations at the first liver biopsy.

A higher prevalence of $\mathrm{HBV}$ genomic mutations in the core promoter and pre-core regions was observed in patients infected with HBV than in patients co-infected with HBV and HCV.

In the co-infection group a significant difference between the anti-HBe positive versus HBeAg positive subgroup was observed for the G1896A/G1899A mutations $(\mathrm{p}=0.007$ and $\mathrm{p}=0.01$, respectively). In the pre-core region in anti-HBe positive patients, the presence of these mutations was associated with lower HBV DNA levels than in HBeAg positive patients, but the presence of these mutations had no impact on the HCV RNA levels.

Overall, the presence of mutations in the HBV genomic regions investigated, either single or multiple, did not correlate with the HAI or progression of fibrosis. 


\section{Serum cytokines}

Table III shows the serum cytokine levels at the time of the first liver biopsy. There were no significant differences in the serum cytokine levels of the patients, except for the TNF- $\alpha$ and IL-8 levels, which were significantly higher in the anti-HBe positive subgroup of HBV patients. The levels of these cytokines were not correlated with the HBV DNA levels or histological damage of the liver or fibrosis scores.

\section{Liver histology at the time of the first biopsy}

The HAI and liver fibrosis scores, performed after a median period of about 12 years post infection, are shown in Table I. At the time of the first biopsy no patient showed liver cirrhosis.

\section{Interferon treatment}

Treatment with $\alpha$-IFN was started after the first liver biopsy in 41 patients; it was well tolerated and no drop outs were observed.

At the end of the treatment none of the 18 co-infected patients cleared HBV DNA and/or HCV RNA (Figure 1).

In the HBV group, $5(36 \%) \mathrm{HBeAg}$ positive patients and none of the anti-HBe positive cleared HBV DNA (Figure 2).

\section{Viral status during the post-treatment follow up}

In the group with $\mathrm{HBV}$ and $\mathrm{HCV}$ co-infection, $8 \mathrm{HBeAg}$ positive patients cleared $\mathrm{HCV}$ RNA and 1 both HBV DNA and HCV RNA; in the anti-HBe positive group only 1 patient cleared HCV RNA ( $p=0.06$; Figure 1). During the follow up, $9(50 \%)$ treated patients and $1(11 \%)$ untreated patient with co-infection with HBV and HCV cleared HCV RNA ( $\mathrm{p}=0.052)$. HCV RNA clearance was observed between 1 and 5 years of post-treatment follow up. There were no differences in the pre-treatment serum HCV RNA levels or HCV genotype between patients who cleared HCV RNA and those who did not. 
In the HBV group $2 \mathrm{HBeAg}$ positive patients and 2 anti-HBe positive cleared HBV DNA (Figure 2). Clearance of HBV DNA throughout the observation period was higher in the $\mathrm{HBeAg}$ positive group ( 7 patients) than in the anti-HBe positive group ( 2 patients; $p<0.01$ ).

In patients who did not clear $\mathrm{HBV}$ and/or HCV viral load, the viremia levels decreased during the follow up (Table IV).

HBeAg seroconversion was observed in $7(58 \%)$ of the co-infected patients and in $9(64 \%)$ with a single HBV infection.

\section{Analysis of factors associated with the development of cirrhosis and HCC.}

The factors associated with the development of liver cirrhosis and HCC were evaluated by uni- and multivariate analysis. Included in the analysis were the following variables: age at infection, duration of disease, gender, co-infection with $\mathrm{HBV}$ and $\mathrm{HCV}, \mathrm{HBeAg}$ /anti-HBe-status, serum levels of HBV DNA and HCV RNA, genomic mutations of HBV, interferon treatment and alcohol intake (>20 g/day). At multiple logistic regression analysis, alcohol intake $(\mathrm{OR}=9.5 \pm 1.2$; 95\% CI $=6.6-13.9 ; \mathrm{p}<0.0001)$ was an independent factor associated with the development of liver cirrhosis and HCC.

\section{Long-term outcome: development of cirrhosis and HCC}

The long-term outcome was evaluated from the date of infection until a stable (about 1 year) HBV DNA or HCV RNA disappearance. Figure 3 shows the liver staging at the end of the follow up. None of the patients showed HBsAg/anti-HBs seroconversion.

\section{Group with HBV and HCV co-infection:}

After a median follow-up period of 23 years (range: 17-40 yrs), 2 patients (7.4\%), one HBeAg positive and one anti-HBe positive, showed cirrhosis, 19 and 23 years post infection, respectively, and one anti-HBe positive patient developed $\mathrm{HCC}(3.4 \%) 36$ years post infection. These three patients were male, did not respond to previous $\alpha$-IFN treatment and two of them had a significant alcohol intake (> $60 \mathrm{~g} /$ daily). The diagnosis of cirrhosis was histologically established; the patients were followed up for a further 6-8 years and showed no sign of liver de-compensation. 


\section{Group with HBV infection only:}

After a median follow-up period of 21 years (range: 16-34 yrs), only one male developed cirrhosis.

\section{Yearly rate of progression of fibrosis}

Assuming a steady linear progression, the yearly rate of fibrosis was calculated by dividing the score of fibrosis by the duration of infection. Although in clinical practice and in the single patient the yearly rate of fibrosis may be questioned because progression of liver fibrosis may not be linear, it is used [Poynard et al, 1997; Adinolfi et al, 2001] to describe the overall long-term rate of progression of liver fibrosis in cohorts of chronic hepatitis patients. Among the co-infected patients, the mean annual progression rate was $0.07 \pm 0.03$, with no differences between the $\mathrm{HBeAg}$ positive and anti HBe positive groups.

In the patients infected with HBV only, the mean annual rates were $0.11 \pm 0.06$ and $0.05 \pm 0.01$ in the anti-HBe positive and $\mathrm{HBeAg}$ positive, respectively $(\mathrm{p}<0.004)$. 


\section{Discussion}

This prospective study shows that co-infection with HBV and HCV acquired early in life has an overall low progression rate $(0.07$ per year) of liver fibrosis over a median follow up of 23 years and as long as 40 years. Advanced disease was observed in $11 \%$ of the cases and was associated with male gender and a long-term history of alcohol intake, which may have contributed to the development of the advanced liver disease [Reuben, 2008]. The progression of the liver disease in patients co-infected with $\mathrm{HBV}$ and $\mathrm{HCV}$ mirrors that of patients with $\mathrm{HBV}$ infection only. In the latter group the majority of cases had a relatively mild chronic liver disease, and cirrhosis was seen in one patient (3.7\%). However, among the patients infected with HBV only, those who were anti-HBe positive had a significantly higher progression rate than the $\mathrm{HBeAg}$ positive.

The data of this study are in sharp contrast with those of retrospective cross-sectional studies conducted on adults, which reported a more severe liver disease with a higher prevalence of cirrhosis in patients co-infected with HBV and HCV [Sagnelli,et al, 2000; Mathurin et al, 2000]. The results of the cross-sectional studies may have been influenced by several factors. First, in those studies the precise moment of infection is unknown, so the follow up refers to the years of clinical observation rather than to the real duration of the disease, which may be much longer and account for the higher severity of the disease. This hypothesis is supported by the fact that the mean age of our patients was less than 40 years whereas the mean age of patients in the cross-sectional studies was higher. Second, cross-sectional studies [Sagnelli, et al, 2000; Mathurin et al, 2000] were conducted on patients hospitalised or referred to hospital, and therefore with more advanced liver disease. Third, we cannot exclude that the infection acquired in youth may have a more favourable long-term outcome. In this respect, it is known that children who acquire hepatitis viruses from their mother show an asymptomatic infection and mild chronic hepatitis in most cases. These patients often show the phenomenon of viral "tolerance" (particularly in HBV infection), with high viremia levels, low ALT levels and a slow progression rate of the disease [Broderick \& Jonas, 2003; 
European Paediatric Hepatitis C Virus Network, 2005; Mast et al, 2005; Bortolotti et al, 2006; Iorio et al, 2007]. Moreover, in patients who acquired HCV infection by transfusion, the risk of developing liver cirrhosis, after a median follow up of 18 years, was related to the age at infection, i.e., lower in patients who were 20 years old or less at the time of infection [Minola et al, 2002]. To answer the question whether age at the acquisition of infection may modulate the progression of the disease a longer follow up of our patients is necessary, as well as prospective studies that include subjects who acquired their infection as adults.

HBV gene mutations seem to be associated with a more advanced liver disease and HCC, but no definitive conclusions can be drawn [Brunetto et al 1991; Chu et al, 2002; Liu et al, 2006]. In this study, HBV mutations were more frequent in anti-HBe positive patient,s regardless of HCV coinfection. None of the single or multiple mutations observed in the HBV genome was associated with increased liver inflammation or progression of fibrosis. De Metri et al. [2006] reported that mutation T1936C accelerates the progression of disease in patients co-infected with HBV and HCV. In our co-infected patients this mutation was not found, and few mutations in the core region involving the well-defined B (aa. 74-81) and T (aa 12-21) cell epitopes were observed. Therefore, the absence of mutation T1936C, associated with the few core mutations found, supports the hypothesis that the antigen presentation and immune response are modified in these subjects, explaining the mild course of infection in these patients [Jung \& Pape, 2002; Barboza et al, 2007]. However, in-vitro studies are necessary to clarify this point.

It has been reported that the progression of liver damage could be correlated with an imbalance in the Th1-Th2 cytokines in patients with HBV or HCV infection [Gonzales-Amaro et al, 1994; Gramenzi et al, 2005]. In this study there were no significant differences in the serum levels of Th1 and Th2 cytokines in the groups studied and, what is more pertinent, none of the alterations observed was associated with advanced liver disease.

A significant number of patients in this study were treated with a schedule of $\alpha$-IFN that is considered certainly inadequate at present. However, in patients co-infected with HBV and HCV, 
$\alpha$-IFN treatment did not produce any favourable response at the end of treatment, but during the post-treatment follow up, a higher number of patients cleared HCV RNA in the treated group than in the untreated group ( $50 \%$ vs $11 \%$, respectively; $\mathrm{p}=0.052$ ). Thus, the data seem to indicate that $\alpha$ IFN treatment does not have a direct effect on HBV or HCV but it might boost the immune system in clearing HCV RNA, particularly in patients with low baseline levels of viremia, and in reducing HBV DNA levels. However, the clinical impact of HCV RNA clearance is doubtful, considering that over the observation period there was no difference in the progression of disease or viremia levels, regardless of a single or co-infection.

In patients with $\mathrm{HBV}$ infection only, $\alpha$-IFN treatment seems to be more effective for the $\mathrm{HBeAg}$ positive patients, who cleared HBV DNA in $36 \%$ of cases, whereas no clearance of HBV DNA was observed in anti-HBe positive patients (Figure 2).

In conclusion, the results of this prospective long-term follow-up study (median 23 years) show that patients with co-infection with HBV and HCV or HBV infection only, when acquired in youth, do not have spontaneous or $\alpha$-IFN-induced seroconversion to anti-HBs. They also have a favourable clinical outcome, the majority of patients having a low rate of progression of the liver disease, no liver failure and a low emergence of HCC. Alcohol intake increased by 9.5 times the risk of developing "early" cirrhosis or HCC. Having acquired the infection in youth these patients have a long life-expectancy but a more severe status of liver disease is possible in the future. A longer follow up is necessary to evaluate further the progression of the disease and whether other factors, besides alcohol, may be associated with a delayed development of cirrhosis and HCC. 


\section{Acknowledgments}

The Authors thank Dr. Adriana Boemio and Ms Geltrude Fiorillo for technical assistance and Ms Serafina Verde and Mr Vincenzo Vaccaro for nursing assistance.

Author disclosure: Authors have no financial or other conflict of interest to disclose.

Financial support: This study was supported by a grant from the Regione Campania, Italy. 


\section{References}

Adinolfi LE, Utili R, Andreana A, Tripodi MF, Marracino M, Gambardella M, Giordano M, Ruggiero G. 2001. Serum HCV RNA levels correlate with histological liver damage and concur with steatosis in progression of chronic hepatitis C. Dig Dis Sci 46:1677-1683.

Barboza L, Salmen S, Goncalves L, Colmenares M, Peterson D, Montes H, Cartagirone R, Gutiérrez Mdel C, Berrueta L. 2007. Antigen-induced regulatory T cells in HBV chronically infected patients. Virology 368:41-49.

Bedossa P, Poyrard T, The French METAVIR Cooperative Study Group. 1996. An algorithm for grading activity in chronic hepatitis C. Hepatology 24:289-243

Bortolotti F, Guido M, Bartolacci S, Cadrobbi P, Crivellaro C, Noventa F, Morsica G, Moriondo M, Gatta A. 2006. Chronic hepatitis B in children after e antigen seroclearance: final report of a 29-year longitudinal study. Hepatology 43:556-562.

Brunetto MR, Giarin MM, Olivieri F, Chiaberge E, Baldi M, Alfarano A, Serra A, Saracco G, Verme G, Will H. 1991. Wild type and e antigen-minus hepatitis B viruses and course of chronic hepatitis Proc Natl Acad Sci USA 88:4186-4190

Broderick AL, Jonas MM. 2003. Hepatitis B in children. Semin Liver Dis 23:59-68.

Castera L, Forns X, Alberti A. 2008. Non-invasive evaluation of liver fibrosis using transient elastography. J Hepatol 48:835-847.

Chu CM, Yeh CT, Lee CS, Sheen IS, Liaw YF. 2002. Precore stop mutant in HBeAg positive patients with chronic hepatitis B: clinical characteristics and correlation with the course of HBeAg-to anti-HBe seroconversion. J Clin Microbiol 40:16-21.

De Mitri MS, Cassini R, Morsica G, Bagaglio S, Andreone P, Loggi E, Muratori P, Bernardi M. 2006. Virological analysis, genotypes and mutational patterns of the HBV precore/core gene in HBV/HCV-related hepatocellular carcinoma. J Viral Hepat 13:574-581. 
European Paediatric Hepatitis C Virus Network. 2005. Three broad modalities in the natural history of vertically acquired hepatitis C virus infection. Clin Infect Dis41:45-51

Friedt M, Gerner P, Lausch E, Trubel H, Zabel B, Wirth S. 1999. Mutations in the basic core promoter and the precore region of hepatitis B virus and their selection in children with fulminant and chronic hepatitis B. Hepatology 29:1252-1258.

Gaeta GB, Stornaiuolo G, Precone DF, Lobello S, Chiaramonte M, Stroffolini T, Colucci G, Rizzetto M. 2003. Epidemiological and clinical burden of chronic hepatitis B virus/hepatitis C virus infection. A multicenter Italian study. J Hepatol 39:1036-1041.

Gilles PN, Fey G, Chisari FV. 1992. Tumor necrosis factor alpha negatively regulates hepatitis B virus gene expression in transgenic mice. J Virol 66:3955-3960.

Gonzales-Amaro R, Garcia-Monzon C, Garcia Buey L, Moreno-Otero R, Alonso JL; Yague E, Pivel JP, Lopez-Cabrera M, Fernandez-Ruiz E, Sanchez-Madris F. 1994. Induction of tumor necrosis factor alpha production by human hepatocytes in chronic viral hepatitis. J Exp Med 179:841-848.

Gramenzi A, Andreone P, Loggi E, Foschi FG, Cursaro C, Margotti M, Biselli M, Bernardi M. 2005. Cytokine profile of peripheral blood mononuclear cells from patients with outcomes of hepatitis C virus infection. J Viral Hepat 12:525-530.

Iorio R, Giannattasio A, Cirillo F, D’Alessandro L, Vegnente A. 2007. Long-term outcome in children with chronic hepatitis B: a 24-year observation period. Clin Infect Dis 45:943949.

Jardi R, Rodriguez F, Buti M, Costa X, Montserrat C, Galman R, Esteban R, Guardia J. 2001. Role of hepatitis B, C and D viruses in dual and triple infection: influence of viral genotypes and hepatitis B precore and basal promoter mutations on viral replicative interference. Hepatology 34:404-410.

Jung MC, Pape GR. 2002. Immunology of hepatitis B infection. Lancet Infect Dis. 2:43-50. 
Knodell RG, Ishak KG, Black WC, Chen TS, Craig R, Kaplowitz N, Kiernan TW, Wollman J. 1981. Formulation and application of a numerical scoring system for assessing histological activity in asymptomatic chronic active hepatitis. Hepatology 5:431-435.

Lauer GM, Walker BD. Hepatitis C virus infection. 2001 N Engl J Med 345:41-52.

Lavanchy D. Hepatitis B virus epidemiology, disease burden, treatment, and current and emerging prevention and control measures. 2004. J Viral Hepat 11:97-107.

Liaw YF. Role of hepatitis C virus in dual and triple hepatitis virus infection.1995. Hepatology 22:1001-1008.

Lindh M, Hannoun C, Dhillon AP, Norkrans G, Horal P. 1999. Core promoter mutations and genotypes in relation to viral replication and liver damage in east Asian hepatitis B virus carriers. J Infect Dis 179:775-782.

Liu CJ, Chen BF, Chen PJ, Lai My, Huang WL, Kao Jh, Chen DS. 2006. Role of hepatitis B viral load and basal core promoter mutation in hepatocellular carcinoma in hepatitis B carriers. J Infect Dis 193:1258-1265.

Marcellin P, Asselah T, Boyer N. Fibrosis and disease progression in hepatitis C. 2002. Hepatology 36 Supp 1:S47-56

Marcellin P, Ziol M, Bedossa P, Douvin C, Poupon R, de Lédinghen V, Beaugrand M. 2008. Non-invasive assessment of liver fibrosis by stiffness measurement in patients with chronic hepatitis B. Liver Int. Jul 9. [Epub ahead of print]

Mast EE, Hwang LY, Seto DSY, Nolte FS, Nainan OV, Wurtzel H, Alter MJ. 2005. Risk factors for perinatal transmission of hepatitis $\mathrm{C}$ virus $(\mathrm{HCV})$ and natural history of $\mathrm{HCV}$ infection acquired in infancy. J Infect Dis 192:1880-1889.

Mathurin P, Thibault V, Kadidja K, Ganne-carrieé N, Moussalli J, El Younsi M, Di Martino V, Lunel F, Charlotte F, Vidaud M, Opolon P, Poynard T. 2000. Replication status and histological features of patients with triple $(B, C, D)$ and dual $(B, C)$ hepatic infection. J Viral Hep 7:15-22. 
Minola E, Prati D, Suter F, Maggiolo F, Caprioli F, Sonzogni A, Fraquelli M, Paggi S, Conte D. 2002. Age at infection affects the long-term outcome of transfusion-associated chronic hepatitis C. Blood 99:4588-4591.

Pontisso P, Ruvoletto MG, Fattovich G, Chemello L, Gallorini A, Ruol A, Alberti A. 1993. Clinical and virological profiles in patients with multiple hepatitis virus infections. Gastroenterology 105:1529-1533

Poynard T, Bedossa P, Opolon P. 1997. Natural history of progression of liver fibrosis in patients with chronic hepatitis C. The OBSVIRC, METAVIR, CLINIVIR, and DOSVIRC groups. Lancet 349:825-832.

Raimondo G, Brunetto MR, Pontisso P, Smedile A, Maina AM, Saitta C, Squadrito G, Tono N; Associazione Italiana Studio Fegato Cooperative Group. 2006. Longitudinal evaluation reveals a complex spectrum of virological profiles in hepatitis B virus/hepatitis $\mathrm{C}$ virus coinfected patients. Hepatology 43:100-107

Reuben A. 2008. Alcohol and the liver. Curr Opin Gastroenterol 24:328-338.

Sagnelli E, Coppola N, Scolastico C, Filippini P, Santantonio T, Stroffolini T, Piccinino F. 2000. Virologic and clinical expression of reciprocal inhibitory effect of hepatitis B, C and delta viruses in patients with chronic hepatitis. Hepatology 32:1106-1110.

Sandrin L, Fourquet B, Hasquenoph JM, Yon S, Fournier C, Mal F, Christidis C, Ziol M, Poulet B, Kazemi F, Beaugrand M, Palau R. 2003. Transient elastography: a new noninvasive method for assessment of hepatic fibrosis. Ultrasound Med Biol 29:1705-1713. Scheuer PJ. 1991. Classification of chronic viral hepatitis: a need for reassessment. J Hepatol 13:372-374.

Utili R, Zampino R, Bellopede P, Marracino M, Ragone E, Adinolfi LE, Ruggiero G, Capasso M, Indolfi P, Casale F, Martini A, Di Tullio MT. 1999. Dual and single Hepatitis $\mathrm{B}$ and $\mathrm{C}$ virus infections in childhood cancer survivors: long-term follow up and effect of interferon treatment. Blood 94:4046-4052. 
Yeh CT, Chiu CT, Tsai SL, Hong ST, Chu CM, Liaw YF. 1994. Absence of precore stop mutant in chronic dual (B and C) and triple (B, C, and D) hepatitis virus infection. $\mathrm{J}$ Infect Dis 170:1582-1585.

Zampino R, Marrone A, Cirillo G, del Giudice EM, Utili R, Karayiannis P, Liang TJ, Ruggiero G. 2002. Sequential analysis of hepatitis B virus core promoter and precore regions in cancer survivor patients with chronic hepatitis B before, during and after interferon treatment. J Viral Hepat. 9:183-188.

Zampino R, Marrone A, Karayiannis P, Cirillo G, del Giudice EM, Rania G, Utili R, Ruggiero G. 2002. Core promoter mutations 3 years after anti-hepatitis B e seroconversion in patients with chronic hepatitis B or hepatitis B and C infection and cancer remission. Am J Gastroenterol 97:2426-2431. 


\section{LEGEND OF FIGURES}

Figure 1. Effect of $\alpha$-interferon treatment in patients co-infected with $\mathrm{HBV}$ and HCV.

Figure 2. Effect of $\alpha$-interferon treatment in patients infected with HBV only.

Figure 3. Long-term outcome of co-infection with $\mathrm{HBV}$ and $\mathrm{HCV}$ and $\mathrm{HBV}$ infection alone acquired in youth 
Table I. General features of patients at the first liver biopsy

\begin{tabular}{lll}
\hline PATIENTS & HBV-HCV & HBV \\
\hline
\end{tabular}

\begin{tabular}{|c|c|c|c|c|c|}
\hline & HBeAg + & Anti-HBe + & HBeAg + & Anti-HBe + & $\mathbf{P}=$ \\
\hline Number of patients & 15 & 12 & 14 & 13 & \\
\hline Gender M/F & $8 / 7$ & $9 / 3$ & $8 / 6$ & $11 / 2$ & \\
\hline $\begin{array}{l}\text { Median age at } \\
\text { infection, yrs } \\
\text { (range) }\end{array}$ & $6(2-16)$ & $10(0.2-16)$ & $14(10-17)$ & $9(6-16)$ & \\
\hline $\begin{array}{l}\text { Median HBV DNA } \\
\text { cps/ml x } 10^{5} \text { (range) }\end{array}$ & $\begin{array}{c}387 \\
(0.00007- \\
1400)\end{array}$ & $\begin{array}{c}0.17 \\
(0.015-1.1)\end{array}$ & $\begin{array}{c}330 \\
(15-1000)\end{array}$ & $\begin{array}{c}2 \\
(0.056-890)\end{array}$ & $\begin{array}{l}0.001^{*} \\
0.001^{\circ} \\
0.001^{\wedge}\end{array}$ \\
\hline $\begin{array}{c}\text { HBV genotype: } \\
\text { A } \\
\text { D }\end{array}$ & $\begin{array}{c}1 \\
14\end{array}$ & 12 & 14 & 13 & \\
\hline $\begin{array}{l}\text { Median HCV RNA } \\
\text { cps/ml x } 10^{5} \text { (range) }\end{array}$ & $\begin{array}{c}2 \\
(0.0001-190)\end{array}$ & $\begin{array}{c}11 \\
(0.006-500)\end{array}$ & - & - & \\
\hline $\begin{array}{c}\text { HCV genotype: } \\
1 \\
2 \\
3 \\
\text { nd }\end{array}$ & $\begin{array}{l}11 \\
4\end{array}$ & $\begin{array}{l}8 \\
2 \\
2\end{array}$ & 2 & - & \\
\hline $\begin{array}{l}\text { Median ALT x } \\
\text { NV(range) }\end{array}$ & $1.4(1.2-9.3)$ & $1.6(1.2-6.1)$ & $2.0(1.6-11)^{\wedge}$ & $3.2(1.1-15.1)^{\wedge}$ & $\begin{array}{l}0.002^{\S} \\
0.002^{*}\end{array}$ \\
\hline $\begin{array}{c}\text { HAI score } \\
\text { median (range) }\end{array}$ & $2(1-8)$ & $3(1-5)$ & $3(1-7)$ & $4(1-10)$ & \\
\hline $\begin{array}{l}\text { Fibrosis score, } \\
\text { median (range) }\end{array}$ & 1 (1, all pts $)$ & $1(1-3)$ & $1(0-1)$ & $2(1-2)$ & \\
\hline
\end{tabular}

nd= not detectable; HAI Histological Activity Index;* HBV-HCV group (anti-HBe positive) vs HBV group (anti-HBe positive); ${ }^{\circ} \mathrm{HBV}$ group (HBeAg positive) vs $\mathrm{HBV}$ group (anti-HBe positive);^ $\mathrm{HBV}-\mathrm{HCV}$ group (HBeAg positive) vs HBV-HCV group (anti-HBe positive); ${ }^{\S} \mathrm{HBV}-\mathrm{HCV}$ group (HBeAg positive) vs HBV group (HBeAg positive) 
Table II. HBV genomic analysis at the first liver biopsy
PATIENTS
HBV-HCV
HBV

\begin{tabular}{|c|c|c|c|c|c|}
\hline & HBeAg + & Anti-HBe + & HBeAg + & Anti-HBe + & $\mathbf{P}=$ \\
\hline $\begin{array}{c}\text { Number of } \\
\text { patients }\end{array}$ & 14 & 12 & 14 & 13 & \\
\hline \multicolumn{6}{|c|}{$\frac{\text { Core promoter }}{\underline{\text { mutations: }}}$} \\
\hline $\mathrm{A} 1762 \mathrm{~T}$ & $2(14 \%)$ & $4(33 \%)$ & $2(14 \%)$ & $7(53 \%)$ & $0.03^{\circ}$ \\
\hline G1764A & $2(14 \%)$ & $4(33 \%)$ & $3(21 \%)$ & $9(75 \%)$ & $\begin{array}{l}0.06^{*} \\
0.01^{\circ} \\
0.02^{\wedge}\end{array}$ \\
\hline \multicolumn{6}{|c|}{$\underline{\text { Pre-core }}$} \\
\hline G1896A & $1(7 \%)$ & $7(58 \%)$ & 0 & $10(76 \%)$ & $\begin{array}{c}0.000003^{\circ} \\
0.007^{\wedge}\end{array}$ \\
\hline G1899A & $1(7 \%)$ & $6(50 \%)$ & 0 & $7(53 \%)$ & $\begin{array}{c}0.001^{\circ} \\
0.01^{\wedge}\end{array}$ \\
\hline \multicolumn{6}{|c|}{ Core mutations: } \\
\hline $\mathrm{T} 12 \mathrm{~S}$ & 0 & $2(16 \%)$ & 0 & $8(61 \%)$ & $0.02 *$ \\
\hline E40D & 0 & $1(8 \%)$ & $2(14 \%)$ & $8(61 \%)$ & $0.007^{*}$ \\
\hline V73G/N & $12(85 \%)$ & $1(8 \%)$ & $8(57 \%)$ & $9(64 \%)$ & $0.003^{*}$ \\
\hline A79I & $10(71 \%)$ & $1(8 \%)$ & $7(50 \%)$ & 0 & \\
\hline
\end{tabular}

${ }^{\circ} \mathrm{HBV}$ group (HBeAg positive) vs HBV group (anti-HBe positive); * HBV-HCV group (anti-HBe positive) vs HBV group (anti-HBe positive); ^ $\mathrm{HBV}-\mathrm{HCV}$ group (HBeAg positive) vs HBV-HCV group (anti-HBe positive). 
Table III. Th1-Th2 cytokine profiles at the first liver biopsy

\begin{tabular}{|c|c|c|c|c|c|}
\hline \multicolumn{2}{|l|}{ PATIENTS } & \multicolumn{2}{|l|}{ HBV-HCV } & \multicolumn{2}{|l|}{ HBV } \\
\hline & HBeAg + & Anti-HBe + & HBeAg + & Anti-HBe + & $\mathbf{P}=$ \\
\hline Number of patients & 14 & 12 & 14 & 13 & \\
\hline \multicolumn{6}{|l|}{$\begin{array}{l}\text { Th1 cytokine values: } \\
\text { pg/ml; median } \\
\text { (range) }\end{array}$} \\
\hline IL 2 & $6.8(1-69.7)$ & $4.35(1.5-31.7)$ & $\begin{array}{l}11.4(0.98- \\
37.1)\end{array}$ & $13.5(1-159)$ & \\
\hline IL 12 & $3.75(2-34.6)$ & $5.5(4-609)$ & $2(0.2-6.7)$ & $4.5(1.5-37.8)$ & \\
\hline$\gamma$-IFN & $8.9(3-65.9)$ & $102(0.5-1557)$ & $8.64(3.7-28-1)$ & $7.6(1-44.6)$ & \\
\hline TNF- $\alpha$ & $\begin{array}{c}31.85(7.5- \\
724)\end{array}$ & $28(1.5-833)$ & $8.47(2.6-53)$ & $\begin{array}{l}68.7(1.5- \\
3300)\end{array}$ & $\begin{array}{l}0.040^{*} \\
0.016^{\circ}\end{array}$ \\
\hline \multicolumn{6}{|l|}{$\begin{array}{l}\text { Th2 cytokine values: } \\
\text { pg/ml; median } \\
\text { (range) }\end{array}$} \\
\hline IL 4 & $4(2-12.8)$ & $3.5(2-7.5)$ & $3.61(2.1-15.3)$ & $3.5(2.5-53)$ & \\
\hline IL 8 & $14.9(6.7-66.1)$ & $10(2.5-299)$ & $48.43(1-155)$ & $13.3(4-46.3)$ & $\begin{array}{l}0.007^{*} \\
0.021^{\circ}\end{array}$ \\
\hline IL 10 & $3(1-58.9)$ & $3.45(2-8.8)$ & $2.7(2.1-5.7)$ & $4.5(1-45.9)$ & \\
\hline IL 13 & $233.3(4-764)$ & $101(0.5-1577)$ & $208(75.5-701)$ & $475(24-4900)$ & \\
\hline
\end{tabular}

* HBV group (HBeAg positive) vs HBV group (anti-HBe positive); ${ }^{\circ} \mathrm{HBV}-\mathrm{HCV}$ group (HBeAg positive) vs HBV group (HBeAg positive). 
Table IV. Characteristics of patients at the end of follow up

\begin{tabular}{lll}
\hline PATIENTS & HBV-HCV & HBV \\
\hline
\end{tabular}

\begin{tabular}{|c|c|c|c|c|c|}
\hline & HBeAg + & Anti-HBe + & HBeAg + & Anti-HBe + & $\mathbf{P}=$ \\
\hline Number of patients & 14 & 12 & 14 & 13 & \\
\hline $\begin{array}{c}\text { End of follow-up } \\
\text { period; median } \\
\text { years post-infection } \\
\text { (range) }\end{array}$ & $23(17-32)$ & $23(18-40)$ & $21(16-32)$ & $21(16-34)$ & \\
\hline $\begin{array}{l}\text { Median HBV DNA } \\
\text { cps/ml x } 10^{5} \text { (range) }\end{array}$ & $\begin{array}{c}0.16 \\
(0.013-1000)\end{array}$ & $\begin{array}{c}0.02 \\
(0.0005-2)\end{array}$ & $\begin{array}{c}1 \\
(0.1-621)\end{array}$ & $\begin{array}{c}0.031 \\
(10-100)\end{array}$ & ${ }^{\wedge} 0.070$ \\
\hline $\begin{array}{c}\text { Median HCV RNA } \\
\text { cps/ml x 10 } \\
\text { (range) }\end{array}$ & $10(3.1-76)$ & $12(0.6-93)$ & - & - & \\
\hline $\begin{array}{l}\text { Median ALT x } \\
\text { NV(range) }\end{array}$ & $1.2(1-1.7)$ & $1.3(1.1-3.5)$ & $1.2(1-1.5)$ & $1.3(1-4.5)$ & \\
\hline $\begin{array}{c}\text { Fibrosis* score at } \\
\text { the end of follow- } \\
\text { up period, median } \\
\text { (range) }\end{array}$ & $1(1-4)$ & $1(1-4)$ & $1(0-2)$ & $2(1-4)$ & \\
\hline
\end{tabular}

*Evaluated by liver biopsy or transient elastography; ^ HBV-HCVgroup (HBeAg positive) vs HBV-HCV group (anti-HBe positive); 